Prace Literackie LIX

Wrocław 2019

https://doi.org/10.19195/0079-4767.59.3

ELŻBIETA SZYNGIEL

ORCID: 0000-0002-2637-4153

Uniwersytet Wrocławski

\title{
Okoliczności wydania poematu Hugo, czyli debiut Słowackiego na łamach „wyborowego co do treści noworocznika”
}

Problem debiutu Juliusza Słowackiego, choć pozornie wydaje się gruntownie przebadany i ostatecznie rozstrzygnięty, nasuwa jednak kilka wątpliwości, które nie znalazły do tej pory odrębnego, całościowego opracowania. W artykułach poświęconych wczesnej twórczości poety kwestia ta traktowana jest zdawkowo, zbywana pojedynczymi wzmiankami, ustępuje miejsca obszerniejszym opracowaniom innych tekstów, które zostały opublikowane przez poetę w latach młodzieńczych.

Omówienie problemu debiutu Juliusza Słowackiego należałoby zacząć od zdefiniowania wskazanego fenomenu w celu rozstrzygnięcia, czy za debiut należy uznać pierwsze, nieopublikowane, wprawki poetyckie, pierwszy tekst drukowany czy może dopiero pierwszy tom poetycki, zawierający ułożony w pewną logiczną całość cykl utworów charakteryzujących się występowaniem ogólnych tendencji i mód literackich.

W kalendariach twórczości poetyckiej Słowackiego za rok jego debiutu często uznaje się już 1825, kiedy — polegając na swojej znakomitej znajomości francuskiego - decyduje się on dokonać przekładu wiersza Elegia Alphonse'a de Lamartine ${ }^{1}$. Nie był to debiut sensu stricto, jednak szesnastoletni poeta nie ograniczył się do pracy translatorskiej, ale też zinterpretował thumaczony tekst.

Tak opisana Elegia jest swoistą inicjacją poetycką, a przy tym quasi-manifestem, w którym zarysował się pierwszy szkielet programu ideowego Słowackiego i w którym młody poeta polemizował do pewnego stopnia z Lamartinowską wizją samotnej ludzkiej egzystencji, nieuchronnie zmierzającej ku śmierci, podkreśla-

${ }^{1}$ Por. M. Jonca, Lamartine'a i Stowackiego rozważania o żeglowaniu, „Litteraria” 2009, nr 37, s. 57-67. 
jąc przy tym konieczność nieustannego konfrontowania się ze wzbudzającą grozę doczesnością.

Najwcześniejsza twórczość poety obejmuje nie tylko tłumaczenia poezji Lamartine'a i Thomasa Moore'a, lecz także wiersze Księżyc, Nowy Rok oraz Dumka ukraińska. Według Aliny Kowalczykowej w pierwszych oryginalnych utworach Słowackiego - zarówno przetłumaczonych, jak i autorskich — widoczne jest „lamartynizowanie”, uzupełnione stylizacją sentymentalną, postawą dystansu wobec świata i znużenia życiem, a także odczuwaniem melancholii w kontakcie z romantycznym pejzażem ${ }^{2}$.

W tradycji badawczej za debiut Słowackiego uznaje się pierwszy tom Poezji, który ukazał się nakładem drukarni Pinardów w Paryżu w 1832 roku. W jego skład weszły powieści poetyckie Żmija, Jan Bielecki, Mnich, Arab oraz Hugo, a także wiersz dedykacyjny Do Michała Rola Skibickiego podpułkownika wojsk Rzeczypospolitej Kolumbijskiej.

Tom ten nie spotkał się z szerszym zainteresowaniem czytelników, nawet wśród poetów współczesnych Słowackiemu. Jedna z niewielu pozytywnych wzmianek na jego temat pojawiła się w lwowskim numerze „Rozmaitości”, datowanym na 30 czerwca 1832 roku. Recenzent zauważył, że poezje Słowackiego „należą do najpiękniejszych naszego czasu i zyskują miejsce obok płodów Mickiewicza, Zaleskiego i Goszczyńskiego"3. Bardziej obszernych, entuzjastycznych w tonie recenzji zabrakło; co więcej, z czasem w pierwszych utworach poety zaczęto doszukiwać się wtórności i naśladownictwa ${ }^{4}$.

Chociaż przy próbach stworzenia charakterystyki poetyckiej drogi Słowackiego istotne są zarówno jego pierwsze, młodzieńcze próby translatorskie, jak i wydany własnym sumptem tom poetycki, nie ulega wątpliwości, że jednym z istotnych punktów zwrotnych w literackiej drodze jest publikacja powieści poetyckiej Hugo w noworoczniku „Melitele”. Jest to pierwszy wydany drukiem w całości autorski utwór Słowackiego, z którym mogło zapoznać się większe grono odbiorców i który można uznać za oficjalny debiut poety.

Słowacki napisał powieść poetycką Hugo podczas swojego pobytu w Warszawie. Prace nad utworem rozpoczął 25 października 1829 roku$^{5}$. Tekst został zapisany w tak zwanym rękopisie nicejskim - oprawionym w czerwony safian

${ }^{2}$ A. Kowalczykowa, Stowacki, Warszawa 1994, s. 26-28.

3 [b.a.], [b.t.], „Rozmaitości” 1832, nr 26, s. 221.

4 Józef Bohdan Zaleski w liście do Ludwika Nabielaka pisał: „Poezje Słowackiego niewiele warte $[\ldots]$ to, co sam dodaje do swoich utworów, jest w gruncie rzeczy niewiele warte: Mozaika Mickiewicza i moja, a przy tym dużo własnej miki w szczelinach”, z listu J.B. Zaleskiego do L. Nabielaka z dnia 3 listopada 1832. Por. Korespondencja Józefa Bohdana Zaleskiego, red. D. Zaleski, t. 1, Lwów 1900, s. 27.

${ }^{5}$ Chronologia młodzieńczych utworów wedle Juliusza Kleinera przedstawia się w sposób następujący: Hugo [sierpień 1829], Mindowe [jesień 1929], Mnich [luty 1830], Jan Bielecki [lipiec 1830], Maria Stuart [wrzesień-październik 1830], Arab [listopad 1830]. Por. J. Kleiner, Stowacki, Wrocław 1972, s. 21. 
zeszycie, w którym znalazły się również jego inne poetyckie wprawki młodzieńcze, napisane w latach 1825-1832. Rękopis ten zaginął prawdopodobnie w Paryżu; przypuszcza się, że w 1832 roku$^{6}$.

Hugo łączy elementy powieści gotyckiej z wątkami balladowymi. Od chwili publikacji doszukiwano się w nim nawiązań do Konrada Wallenroda, choć od Mickiewiczowskiej powieści poetyckiej miał różnić się brakiem wątków patriotycznych. Być może właśnie epigoństwo, które nieco pochopnie zarzucono Słowackiemu, sprawiło, że jego „powieść krzyżacka” nie doczekała się w chwili publikacji uwagi i aprobaty czytelników. Inne utwory napisane w tym samym czasie, nawet jeżeli początkowo postrzegane raczej w kategoriach młodzieńczych wprawek i jako próby poszukiwania własnego miejsca w romantycznej rzeczywistości poetyckiej, z czasem doczekały się większego zainteresowania i zostały docenione. Tymczasem poemat Hugo uznano zaledwie za niezbyt udaną powieść o rycerzu krzyżackim, niepozbawioną jednak pewnej oryginalnej myślii ${ }^{7}$; młodzieńczą wprawkę pisarską, atrakcyjną formalnie, ale pozbawioną psychologicznej głę$\mathrm{bi}^{8}$; tekst sytuujący się na pograniczu artystycznego kiczu, będący przykładem zmanierowanego naśladownictwa, a nie twórczej gry z obecnymi w ówczesnej literaturze konwencjami ${ }^{9}$; utwór, w którym wyraźnie uwidoczniły się tendencje Słowackiego do bajronizowania, oryginalny jedynie w zakresie opisywania wrażeń z kontemplacji litewskiego pejzażu ${ }^{10}$; czy wreszcie dzieło łączące elementy powieści gotyckiej i wątki balladowe, wskazujące na nieprzeciętną znajomość historii średniowiecznej ${ }^{11}$.

W badaniach nad wczesną twórczością Słowackiego od dawna ugruntowało się przekonanie o wstecznym i mało oryginalnym charakterze Hugo. Dopiero w ostatnich latach coraz częściej wspomina się o konieczności zrewidowania pewnych sądów na temat tego poematu ${ }^{12}$. Co prawda nie oznacza to, że problemu nie zauważano wcześniej. W latach osiemdziesiątych jako jeden z pierwszych omawiane dzieło poety dowartościował bowiem Marian Ursel, zauważając, że jest to utwór nie tylko kumulujący środki artystyczne stosowane w literaturze gotyckiej, lecz także prezentujący nowy typ bohatera romantycznego, którego motywacje mają wymiar indywidualny, a nie narodowo-patriotyczny ${ }^{13}$.

${ }^{6}$ J.M. Rymkiewicz, Poezyj tom pierwszy i drugi, [w:] idem, Słowacki. Encyklopedia, Warszawa 2004, s. 388-389.

7 J. Kleiner, op. cit., s. 21.

${ }^{8}$ S. Treugutt, Pisarska młodość Stowackiego, Wrocław 1958, s. 97.

9 D. Seweryn, Stowacki nie-mistyczny, Lublin 2001, s. 119.

${ }^{10}$ A. Witkowska, Stowacki, Warszawa 1994, s. 74-75.

11 J. Zieliński, Stowacki. SzatAnioł, Warszawa 2009, s. 80-81.

12 M. Kuziak, Wokót „Pisarskiej młodości Stowackiego” Stefana Treugutta, [w:] idem, Fragmenty o Stowackim, Słupsk 2001, s. 19.

${ }^{13}$ M. Ursel, Wstęp, [w:] J. Słowacki, Powieści poetyckie, Wrocław 1986, s. XIV-XVI, LXVILXIX. 


\section{„Wyborowy co do treści noworocznik”}

Pierwszy autorski utwór Słowackiego ukazał się, jak wspomniano, w 1830 roku na łamach wydawanego w Warszawie noworocznika „Melitele”, nad którym pieczę redaktorską sprawował Antoni Edward Odyniec.

Miano „noworocznika” nadał pismu sam Odyniec. Celem redaktora było zwrócenie uwagi na oryginalność gatunkową dzieła oraz chęć zaakcentowania w ten sposób jegoo odrębności względem wzorców zachodnich, których można szukać wśród almanachów.

Według Janiny Kamionkowej ${ }^{14}$ almanach to publikacja wydawana jednorazowo lub w cyklu rocznym, będąca zbiorem utworów literackich różnych autorów, wyrastająca po części z tradycji literatury jarmarcznej, a po części - z form sylwicznych, przeznaczonych na własny użytek. Almanachy cieszyły się dużą popularnością w drugiej połowie XVIII i na początku XIX wieku, przede wszystkim w Anglii i Niemczech. Na gruncie polskim za pierwowzór gatunku uznaje się „Almanach Lubelski” Klemensa Urmowskiego ${ }^{15}$ oraz „Kolędy” Ludwika Adama Dmuszewskiego ${ }^{16}$. Brakuje jednak w tych pismach charakterystycznych dla tego rodzaju publikacji ornamentyki oraz mnogości form publikowanych na ich łamach (tradycyjne almanachy zawierały wszak między innymi rebusy, szarady, arie, wiersze ulotne), co odróżniało je od podobnych tytułów publikowanych w zachodniej Europie.

Pierwszym almanachem o typowo literackim charakterze, wyróżniającym się elegancką formą i starannym doborem treści, był wydawany od 1822 roku almanach „Flora. Rocznik dla dam”17. Za tytuł, który stanowił bezpośrednie nawiązanie do anglosaskich i niemieckich wzorców wydawniczych, można natomiast uznać almanach ,Jutrzenka. Rocznik poezji w upominku płci pięknej na rok 1824”. Zaprezentowano w nim dokonania ówczesnej szkoły romantycznej, a wiersze dobierano, opierając się na skrystalizowanym programie literackim zbudowanym na przekonaniu o dominacji czucia i wiary nad rozsądkiem. Jednym z głównych celów „Jutrzenki” było propagowanie najnowszych poezji twórców romantycznych, dlatego w jej pierwszym numerze znalazły się wiersze Adama Mickiewicza, Józefa Bohdana Zaleskiego, Kazimierza Brodzińskiego, A.E. Odyńca i Stefana Witwickiego ${ }^{18}$.

14 J. Kamionkowa, Almanachy literackie, [w:] Formy literatury popularnej, red. A. Okopień-Sławińska, Wrocław 1973, s. 141.

15 D. Dziubicka, Drukarnia Karola Pruskiego i jego sukcesorów (1811-1838), [w:] Studia z dziejów drukarstwa i księgarstwa w Lublinie w XIX i XX wieku, red. B. Szyndler, Lublin 1988, s. 97.

${ }^{16}$ J. Kamionka-Straszakowa, Almanach, [w:] Stownik literatury polskiej XIX wieku, red. J. Bachórz, A. Kowalczykowa, Wrocław 2009, s. 13-17.

17 A. Potocki, Sejmiki literackie w dobie romantyzmu: o noworocznikach i almanachach literackich w pierwszej połowie XIX wieku, „Pamiętnik Literacki” 1902, nr 1/4, s. 403.

18 A. Kowalska, Mochnacki $i$ Lelewel. Wspóttwórcy życia umysłowego Warszawy i kraju 1825-1830, Warszawa 1971, s. 47. 
Przytoczone historyczne fakty wskazują, że „Melitele” nie było gatunkiem zupełnie nowym i wcześniej nieznanym na ziemiach polskich. W inicjatywie Odyńca idea almanachu znalazła jednak najpełniejsze odzwierciedlenie, a sam poeta w wydatny sposób przyczynił się do spopularyzowania tego rodzaju publikacji.

Do założenia „Melitele” Odyńca miała zachęcić Rozalia Bisping. W swoich wspomnieniach Odyniec opisał to wydarzenie następująco:

Pan minister Grabowski sprowadził był z Londynu bardzo piękny i kosztowny almanak, z wizerunkami pięknych kobiet angielskich. Gdym więc raz admirował je w gronie panienek, jedna z nich, panna Rozalia Bisping, zaczęła ubolewać, że ja nie jestem malarzem; gdyż mając tyle pięknych panienek, pewno bym o podobnym almanaku pomyślał. Słówko to, żartem i bez celu rzucone, zapaliło nagle we mnie myśl inną. Czemuż bym, mając tylu przyjaciół-poetów, nie mógł wydać wiązanki z ich pieśni? ${ }^{19}$

Z tego cytatu wynika, że pomysł stworzenia almanachu poetyckiego podyktowany był w dużej mierze możliwością wykorzystania znajomości w warszawskim światku literackim i chęcią rozpowszechnienia utworów swoich przyjaciól. Odyniec napisał do znajomych autorów listy z prośbą o nadesłanie własnych dzieł.

Tak więc skoro Odyniec nie chciał kopiować zagranicznej nazwy „almanach”, zdecydował się określać „Melitele” mianem noworocznika. Nazwa ta, jako nieużywana wcześniej, miała podkreślać wyjątkowy charakter publikacji i podobno przyśniła się Odyńcowi, który w środku nocy zapisał ją na kartce, a po kilku dniach podzielił się swoim pomysłem z S. Witwickim ${ }^{20}$. Z dużą dozą prawdopodobieństwa można stwierdzić, że pierwszy numer noworocznika nigdy nie ukazałby się na rynku, gdyby nie życzliwe wsparcie właśnie Witwickiego, który odpowiadał za wszystkie sprawy techniczne i organizacyjne, układał się ,z drukarnią, papiernią, litografią [odpowiadał za - przyp. autorki] całą materialną część wydawnictwa"21.

„Melitele" nie była almanachem programowym związanym z działalnością konkretnej grupy poetyckiej skonsolidowanej wspólną ideą o charakterze filozoficznym, kulturalnym, społecznym lub estetycznym. Odyniec, dobierając materiał, kierował się przede wszystkim własnym gustem i osobistymi sympatiami, chociaż w przedmowie do pierwszego numeru deklarowat:

Korzystając z chlubnej dla mnie znajomości, dobroci lub przyjaźni znakomitszych w kraju naszym pisarzów, starałem się o nadanie „Melitele” literackiej wartości, a umieszczając w niej obok siebie płody rozmaitych autorów, chciałem go niejako uczynić wskazówką rozmaitego ich charakteru i dążenia ${ }^{22}$.

19 A.E. Odyniec, Wspomnienia z przeszłości opowiadane Deotymie, Warszawa 1884, s. 368369.

${ }^{20}$ M. Makaruk, Żywot romantyka poćciwego, [w:] eadem, Antoni Edward Odyniec. Romantyk w zwierciadle biedermeieru, Warszawa 2012, s. 78-79.

21 A.E. Odyniec, Wspomnienia z przeszłości..., s. 24.

22 A.E. Odyniec, Przedmowa wydawcy, „Melitele”, Warszawa 1829, [b.p.]. 
Ostatecznie stworzył publikację raczej poetycką niż publicystyczno-krytyczną, a jego głównym celem było ożywienie życia literackiego i zaspokojenie zainteresowania czytelników spragnionych lektury modnych podówczas utworów zamkniętych w ramach charakterystycznych dla romantyzmu gatunków. Pragnienie dokonania głębszych przeobrażeń życia literackiego kierowało Odyńcem o tyle, że chciał rozsławić nazwiska swoje i swoich młodych kolegów po piórze w wyższych kręgach towarzystwa warszawskiego, natomiast w jego naturze nie leżała, zdaje się, ambicja całkowitego przemodelowania myślenia o sztuce poetyckiej. Jednocześnie przyświecało mu pragnienie, aby odbiorcami treści zawartych w noworoczniku byli raczej wyrobieni czytelnicy, miłośnicy literatury ojczystej, osoby chętnie i często obcujące ze słowem pisanym.

Noworocznik „Melitele” ukazał się dwukrotnie — w 1829 oraz 1830 roku. Pierwszy tom zawierał poezje między innymi A. Mickiewicza, A.E. Odyńca, Aleksandra Fredry, J.B. Zaleskiego, Konstantego Gaszyńskiego, Ignacego Chodźki oraz S. Witwickiego, a także Juliana Ursyna Niemcewicza i Franciszka Morawskiego. Ostatecznie Odyniec udostępnił łamy noworocznika przedstawicielom różnych formacji literackich, przeważały w nim jednak utwory patronów i adeptów szkoły romantycznej. Jego karty stały się ponadto miejscem nieoficjalnych turniejów poetyckich, w których funkcję arbitrów pełnili czytelnicy.

Uwzględniając kwestie dotyczące sztuki wydawniczej, nie można określić „Melitele” mianem typowego almanachu. W założeniu publikacje tego rodzaju miały być wręczane jako upominki gwiazdkowe i noworoczne, dlatego charakteryzowały się elegancją i starannością edytorską. Nadawano im tytuły odwołujące się do mitologii, symboli i alegorii; wyróżniały się ponadto eleganckim papierem w pastelowych kolorach, ozdobnym krojem pisma, złoceniami brzegów kart, inicjałami, winietami, safianowymi oprawami, a teksty opatrywano ilustracjami (przede wszystkim o charakterze sentymentalnym i biedermeierowskim) oraz kunsztownymi inicjałami ${ }^{23}$.

Chociaż Odyniec dołożył wielu starań, aby wydawany przez niego noworocznik przypominał kunsztowne edycje pierwowzorów z innych krajów, nie był w stanie - prawdopodobnie głównie ze względów finansowych - wydawać „Melitele” w formie tak wyrafinowanej, jak tego pragnął. Ślady tej staranności widoczne są jednak w „czystości i staranności druku”24 oraz w zwyczaju umieszczania między poezjami widoków (w tym przypadku zamków litewskich), których zdaniem Odyńca „podania i dzieje, ściśle niekiedy z narodowymi złączone, często są bardzo ciekawe i ważne"25.

„Melitele" odniosła sukces i była bardzo chętnie czytana; przysporzyła dużej popularności również samemu Odyńcowi. Potwierdza to opinia przytoczona

23 J. Kamionka-Straszakowa, op. cit., s. 13.

24 A.E. Odyniec, Przedmowa wydawcy, [b.p.].

${ }^{25}$ Ibidem. 
przez Kazimierza Wójcickiego, która miała być wygłoszona przez nieznanego z nazwiska bywalca jednej z warszawskich kawiarni:

Uściskałbym tego chuchraka Odyńca, żebym go znał, za jego „Melitele”, ale on po żadnych kawiarniach nie chodzi. Tak wyborowych co do treści noworoczników nie znam w żadnej literaturze zagranicznej. Prawda, że są ozdobniejsze co do wydawnictwa, tak pod względem druku, papieru, jak rycin: ale co do pokarmu ducha jakże ubogie! [...] Żeby w Paryżu albo Londynie takie bogactwo doborowych artykułów zgromadzono, jakie daje Odyniec w swojej „Melitele”, a jeszcze to przypstrzyli rycinami, okazałym drukiem i piękną oprawą, setki tysięcy rozbiegłyby się po Europie i ludzie rozdziawialiby gęby ${ }^{26}$.

Odbiór „Melitele” nie był jednak w pełni pozytywny. Wśród jego krytyków znaleźli się — z oczywistych względów — przede wszystkim przedstawiciele szkoły klasycznej, między innymi Kajetan Koźmian, Ludwik Osiński oraz pośrednio - Joachim Lelewel, który w swoim przeglądzie prasy warszawskiej z 1830 roku całkowicie zignorował publikację Odyńca ${ }^{27}$. Niechęć ta w większym stopniu wynikała jednak z osobistych uprzedzeń niż rzeczywistego kwestionowania wartości literackiej utworów zamieszczonych w noworoczniku.

Mimo krytyki ze strony bardziej konserwatywnych środowisk literackich oraz wysokiej ceny pierwszy numer „Melitele” rozszedł się bardzo szybko w nakładzie 1000 egzemplarzy i niemal od razu stał się białym krukiem ${ }^{28}$. Noworocznik zapewnił wydawcy przypływ środków finansowych, dzięki którym mógł opłacić swoje późniejsze podróże po Europie. Drugi i ostatni numer almanachu ukazał się w 1837 roku w Lipsku dzięki staraniom Jana Nepomucena Bobrowicza. Sam Odyniec ostatecznie zarzucił ten projekt na rzecz innych przedsięwzięć literackich, a „Melitele” z czasem odeszło w zapomnienie.

\section{Odyniec jako wydawca}

Działalność wydawnicza Odyńca omawiana jest przede wszystkim w odniesieniu do roli, jaką odegrał w ostatnich latach swojego życia, mianowicie redaktora kierowanej do niego korespondencji. Jako bliski przyjaciel Mickiewicza, a także człowiek, który przez wiele lat był ważną postacią świata literackiego i prowadził ożywioną działalność publicystyczną, zgromadził bogaty zbiór listów. Zbiór ten, będący świadectwem kultury romantycznej, postanowił opublikować w „Kronice Rodzinnej” oraz „Tygodniku Ilustrowanym”.

Ponieważ prywatna korespondencja to niezwykle delikatna materia, a jej udostępnianie ograniczone było konwenansami epoki, Odyniec w wielu przypadkach zdecydował się na ocenzurowanie kierowanych do niego listów. Z tego względu badania nad procesem redagowania „Melitele” są już na wstępie pozbawione

${ }^{26}$ K.W. Wójcicki, Kawa literacka w Warszawie, Warszawa 1873, s. 28.

${ }^{27}$ M. Makaruk, Warszawskie lata Antoniego Edwarda Odyńca, [w:] Romantyzm warszawski, red. O. Krysowski, Warszawa 2016, s. 344-347.

28 A. Pług, Antoni Edward Odyniec, „Kłosy” 1885, nr 1046, s. 46. 
pewnych istotnych elementów, potencjalnie interesujących, tym bardziej, że z zachowanym wzmianek wiemy, jak skomplikowany był cały proces wydawniczy. Trudności z nim związane wynikały przede wszystkim z konieczności zgromadzenia utworów pozwalających zapełnić karty noworocznika.

Prace redakcyjne Odyńca nad wybranymi tekstami drukowanymi w „Melitele" wykraczały daleko poza ramy tradycyjnej adiustacji. Czasami był on przesadnie gorliwy, szczególnie pracując nad tekstami Mickiewicza. Przed opublikowaniem na łamach pierwszego numeru „Melitele” Mickiewiczowskiej ballady Czaty zdecydował się na wprowadzenie do niej kilku istotnych zmian, dotyczących przede wszystkim języka używanego przez postacie, których żywa, potoczna mowa raziła jego gust literacki oraz poczucie przyzwoitości ${ }^{29}$. Za uzasadnienie tych modyfikacji uznał wzmiankę Mickiewicza w jednym z listów skierowanych do niego: „Nie wiem, czy ta ballada może się płci pięknej podobać i czy nie obrazi delikatności warszawskiej. Daję ci pozwolenie odmienić, jak ci się podoba, niektóre szczególne wiersze, nim oryginał, taki jak jest, w swoich poezjach wydrukuję" 30 . Odyniec bardzo dosłownie potraktował uwagę o „delikatności warszawskiej”, redagując tekst wedle własnego uznania.

Nie zdecydował się on jednak na wprowadzenie podobnych zmian w poemacie Hugo Słowackiego, być może ze względu na to, że poetów nie łączyła relacja odpowiednio bliska, by umożliwić redaktorowi noworocznika swobodne dysponowanie otrzymanym tekstem.

\section{Słowacki na łamach „Melitele”}

Kwestia układów towarzyskich między Słowackim a Odyńcem została stosunkowo dobrze opisana w literaturze ${ }^{31}$. Odyniec, starszy od Słowackiego o pięć lat, poznał go w 1821 roku podczas wizyty złożonej w wileńskim domu rodziny Spitznaglów. Odyniec miał wówczas zajrzeć do dziecięcego pokoju i zobaczyć w nim chłopca o szczególnym wyrazie twarzy i dużych, czarnych, błyszczących oczach $^{32}$.

Poeci przez większość życia darzyli się znaczną niechęcią, której źródeł należy szukać w animozjach towarzyskich oraz rywalizacji poetyckiej.

Odyniec, nieustannie podkreślający wyższość talentu Mickiewicza, w swojej korespondencji nie szczędził uwag Słowackiemu, któremu zarzucał pychę i skłonność do wynoszenia się ponad innych. Słowacki nie pozostawał mu dłużny,

${ }^{29}$ S. Łanda, Jak Odyniec redagowat „Czaty” Mickiewicza: z ,, Kroniki życia i twórczości Mickiewicza: 1824-1829”, „Pamiętnik Literacki”1982, nr 1/2, s. 225.

${ }^{30}$ A. Mickiewicz, Dzieła, t. 14. Listy, oprac. S. Pigoń, Warszawa 1955, s. 425.

31 Por. J.M. Rymkiewicz, op. cit., s. 324-328; Z. Sudolski, Stowacki, Warszawa 1996; K. Westermark, Poeta-urzędnik. Juliusz Stowacki w Komisji Rządowej Przychodów i Skarbu w Warszawie (1829-1831), [w:] Romantyzm warszawski, s. 291-323.

32 J. Zieliński, op. cit., s. 57. 
krytykując jego talent literacki i określając mianem „miernego poety”. W liście do Aleksandry Bécu z 15 kwietnia 1829 roku pisał o jego dramacie Felicyta w następujący sposób: „Dzieło wielkiej objętości, a bardzo małych zalet”, i dalej: ,,jeżeli je do końca przeczytasz, to będziesz mogła z księdzem tego dramatu zaśpiewać Te Deum"33.

Odyniec szczególnym przywiązaniem darzył matkę Słowackiego Salomeę Bécu. Dał temu wyraz w swoich Wspomnieniach z przeszłości, w których przyznał, że była pierwszą czytelniczką jego wierszy w czasach przed poznaniem Mickiewicza. Określał ją jako „najłaskawszą przyjaciółkę” i „przewodniczkę pierwszej młodości" ${ }^{34}$. Być może na początku lat dwudziestych Odyniec był kochankiem Salomei ${ }^{35}$, a romans ten legł u podstaw antypatii poetów, którzy wyraz swojej wzajemnej niechęci dawali jeszcze wielokrotnie w listach do przyjaciół, pisanych również w późniejszych latach.

Relacje Słowackiego i Odyńca wydają się w kontekście niniejszych rozważań o tyle istotne, że antagonizm obu mężczyzn może nasuwać pytanie, dlaczego młody poeta mimo to zdecydował się opublikować swój tekst w noworoczniku. Prawdopodobnie zdecydowały o tym względy towarzyskie (bliskie kontakty, jakie utrzymywali Salomea i Odyniec, obracanie się Słowackiego w środowisku warszawskim, w kręgach bliskich Odyńcowi) oraz chęć dotarcia ze swoim dziełem do szerszego grona odbiorców.

Słowacki przybył do Warszawy w lutym 1829 roku i rozpoczął pracę jako szeregowy urzędnik w Komisji Rządowej Przychodów i Skarbu. Przeprowadzka ta zmieniła jego pozycję towarzyską. O ile w Wilnie — w dużej mierze dzięki nazwisku i koligacjom rodzinnym - był znany i intensywnie uczestniczył w tamtejszym życiu salonowym, o tyle po przenosinach pozostawał na obrzeżach kręgów koleżeńskich i artystycznych. Jedną z niewielu osób, które znał jeszcze z Wilna, był właśnie Odyniec. Pomimo niezadowolenia z aktualnej sytuacji życiowej i odczuwanej nudy Słowacki z niezwykłym zapałem oddawał się wówczas pracy literackiej. Starszy poeta, zgodnie z obietnicą złożoną Salomei Bécu, miał być opiekunem i przewodnikiem młodego Juliusza oraz redaktorem jego pierwszych dzieł. Świadczy o tym fragment jednego z listów Słowackiego do Odyńca, dołączony do wiersza Dumka ukraińska:

Zachęconym twoim przyjaznym wezwaniem w liście do Mamy nie ociągam się dłużej i posyłam Ci moją dumkę [...] i postrzeżenia twoje przyjmę z wdzięcznością, pochwałom nie uwierzę, co sam czuję aż nadto, że moja dumka nie jest ich wartą; a choćbyś pomimo tego ostrzeżenia obsypywał mię niezasłużonymi pochwałami, to przyjąłbym je $\mathrm{z}$ takim przykrym poniżenia uczuciem, $\mathrm{z}$ jakim żebrak hardy przyjmuje niezasłużoną $\mathrm{z}$ ręki bogacza jałmużnę ${ }^{36}$.

33 Cyt. za: J.M. Rymkiewicz, op. cit., s. 327-328.

34 Ibidem, s. 324-328.

35 Ibidem.

${ }^{36}$ List J. Słowackiego do A.E. Odyńca z 27 stycznia 1827 roku; cyt. za: E. Kipa, List Stowackiego do A. E. Odyńca i „Dumka ukraińska”, „Pamiętnik Literacki” 1950, nr 1/2, s. 544. 
Inną wskazówką faktograficzną zdającą się potwierdzać domysł o przyczynie publikacji Hugo w „Melitele” może być list Salomei Bécu do Odyńca, datowany na 24 września 1828 roku, w którym matka Słowackiego pisała, że synowi „tak [...] tu nudno, że wierszów pisać nie może i podobno, że nic Panu do almanaku nie da" ${ }^{37}$. Ona sama posyłała Odyńcowi, który stale poszukiwał nowych tekstów, kilka utworów Korzeniowskiego, sugerując jednocześnie, że w swoich planach wydawniczych mógłby uwzględnić również poezję Juliusza. Przytoczone fragmenty dość jednoznacznie wskazują na protekcję Salomei, która z pomocą bliskiego sobie mężczyzny pragnęła wyrobić synowi opinię zdolnego poety i zapewnić sławę.

Odyniec jedynie do pewnego stopnia wywiązał się ze złożonego przyrzeczenia. Ostatecznie w drugim numerze noworocznika znalazł się utwór Juliusza, jednak starszy z poetów nie roztoczył nad młodszym opieki — ani towarzyskiej, ani literackiej. Podstawą głębszych studiów nad zewnętrznymi warunkami publikacji poematu Hugo i relacją między poetami mogłaby stać się ich korespondencja, która jednak nie zachowała się w całości do dzisiaj.

\section{Ocena debiutu Słowackiego}

Zarówno sam Słowacki, jak i jego otoczenie niewiele uwagi poświęcili kwestii debiutu na łamach „Melitele”. Dlaczego poeta, który tak wielką wagę przykładał do własnych sukcesów literackich i uznania ze strony otoczenia, swój pierwszy wydany drukiem utwór pominął niemal całkowitym milczeniem i w korespondencji — zarówno z czasów, kiedy dopiero rozpoczynał swoją artystyczną drogę, jak i z okresu, kiedy był już dojrzałym twórcą — właściwie o nim nie wspominat?

We wskazanym wcześniej rękopisie nicejskim pod datą 15 listopada 1830 roku widnieje notatka następującej treści: „Oddałem do cenzury, a wkrótce oddam do druku moje wiersze: Maria Stuart tragedia, Jana Bieleckiego powieść, Hugona, Mnicha i Araba. Jakiż będzie mój zawód literacki?"38. Przytoczony urywek można traktować jako przejaw stosowanego przez Słowackiego toposu skromności, a także wyraz obawy przed debiutem i niezbadanymi kolejami dalszej kariery literackiej, jednak późniejsze uwagi na temat pierwszych poezji zdają się temu przeczyć. Słowacki zdawał się nie tyle wątpić we własny talent poetycki, ile w ewentualne powodzenie opublikowanych tekstów wśród czytelników. Jego obawy potwierdziły się bardzo szybko, ponieważ już w 1833 roku w przedmowie do trzeciego tomu Poezji opisuje samego siebie jako autora „nie

${ }^{37}$ Z listu S. Bécu do A.E. Odyńca z 24 września 1828 roku; cyt. za: Z. Sudolski, Inedita wieku XIX w zbiorach Skimborowicza, „Pamiętnik Literacki” 1956, nr 3/4, s. 194.

38 E. Sawrymowicz, Kalendarz życia i twórczości Juliusza Słowackiego, współp. S. Makowski, Z. Sudolski, Wrocław 1960, s. 103. 
zachęconego pochwałami, nie zabitego dotąd krytyką" "39, czyli zmagającego się obojętnością odbiorców. W listach do matki poeta wspominał wprawdzie, że jego powieść poetycka Żmija spotkała się z uznaniem i wedle jego czytelników miała być dowodem dużego kunsztu poetyckiego, jednak Eustachy Januszkiewicz zakwestionował pochlebny odbiór pierwszych utworów Słowackiego, stwierdzając, że wszelkie pochwały były „wymarzone w jego wyobraźni” 40 .

Pod koniec lat trzydziestych poeta stwierdził natomiast, że wydanie dwóch pierwszych tomów poezji nie było rozsądne i zaszkodziło jego dalszej karierze literackiej $^{41}$. W polemicznej nocie, opublikowanej w „Młodej Polsce” w 1839 roku, napisał: „Pierwsze tomy poezji moich są bez duszy”, i dalej: „pierwszymi dwoma tomami zgubiłem się na cały czas życia mego i teraz muszę bez echa śpiewać, choć śpiewam inaczej" 42 .

Być może właśnie negatywna ocena własnego debiutu zaważyła na tym, że Słowacki w następnych latach wspominał o nim niechętnie, w ten sposób usuwając go niejako sprzed oczu badaczy skupiających się na innych dziełach, zaliczanych obecnie do jego młodzieńczej twórczości.

Opublikowany na łamach „Melitele” poemat Hugo spotkał się z bardzo niejednolitym przyjęciem. Ukrywający się pod pseudonimem Bezstronnickiego Franciszek Salezy Dmochowski pisał w „Gazecie Korespondenta Warszawskiego i Zagranicznego” „Jakiś bezimienny umieścił w »Meliteli« powieść krzyżacką, wiernie przypominającą Wallenroda i nieoddzielną cechę naśladownictwa — niedołężność. Kiedyż przecie romantycy przestaną naśladować i, co większa, naśladować jedni drugich"43. Ów głos krytyczny jest jednak nie tyle dowodem braku uznania dla talentu poetyckiego Słowackiego, ile kolejnym przykładem ówczesnych animozji między środowiskami klasyków i romantyków, tym bardziej że w dalszej części artykułu recenzent przyznaje, że inne poezje zamieszczone w „Melitele” nie są nawet warte wspomnienia. Zgoła odmiennie debiut Słowackiego został oceniony w „Pamiętniku Umiejętności Moralnych i Literatury", w którym anonimowy krytyk omawiał wszystkie utwory umieszczone w noworoczniku i przewidywał, że autor powieści poetyckiej Hugo, chociaż bezimienny, z pewnością wzbudzi ciekawość publiczności, która będzie „wyglądać więcej płodów jego pióra" 44 .

$\mathrm{Na}$ ambiwalencję w odbiorze Hugo wpłynęły niedostrzeżona wówczas nowa propozycja Słowackiego w zakresie kształtowania modelu bohatera romantycznego, niesłusznie brana za pozbawione głębszej refleksji naśladownictwo. Nie bez

39 J. Słowacki, [Wstęp poety do trzeciego tomu Poezyj], [w:] idem, Powieści poetyckie, s. 195.

${ }^{40}$ Cyt. za: A. Małecki, Juliusz Stowacki: jego życie i dzieła w stosunku do wspótczesnej epoki, Lwów 1901, s. 82.

41 J. Słowacki, Dzieła wszystkie, t. 3, red. J. Kleiner, Wrocław 1952, s. 197-198.

42 Ibidem.

43 [b.a.], [b.t.], „Gazeta Korespondenta Warszawskiego i Zagranicznego” 1830, nr 147, s. 24.

44 [b.a.], „Pamiętnik Umiejętności Moralnych i Literatury”, Warszawa 1830, t. 2, s. 233. 
znaczenia był też odżywający stopniowo spór między klasykami i romantykami, warunkujący odbiór dzieła przez reprezentantów poszczególnych obozów.

Nawet duża perspektywa czasowa nie pozwala na jednoznaczną ocenę podjętej przez Słowackiego decyzji, aby swój pierwszy utwór ogłosić drukiem właśnie w „Melitele”.

Próba oceny debiutu poety może prowadzić jednak do wniosku, że twórca, który pozostawał poza obrębem ówczesnych sporów literackich, nie apostołował na rzecz romantyzmu i nie toczył w jego obronie sporów z klasykami, znalazł się w dobrym miejscu i czasie, a korzystny splot okoliczności życiowych i towarzyskich — pobyt w Warszawie, pewne znajomości w kręgach literackich, zażyłość między Salomeą Bécu i Odyńcem, popularność almanachu jako gatunku sprawiły, że Słowacki zadebiutował w „Melitele”.

Mimo ambiwalentnego stosunku, jaki poeta w późniejszych latach miał do swojej twórczości z lat młodzieńczych, i stosunkowo niewielkiego zainteresowania badaczy poematem Hugo wydaje się, że moment publikacji właśnie tego dzieła należy uznać za początek literackiej drogi Słowackiego.

\section{Bibliografia}

[b.a.], „Gazeta Korespondenta Warszawskiego i Zagranicznego” $1830 \mathrm{nr} 147$.

[b.a.], „Pamiętnik Umiejętności Moralnych i Literatury”, Warszawa 1830, t. 2.

[b.a.], „Rozmaitości” 1832, nr 26.

Dziubicka D., Drukarnia Karola Pruskiego i jego sukcesorów (1811-1838), [w:] Studia z dziejów drukarstwa i ksiegarstwa w Lublinie w XIX i XX wieku, red. B. Szyndler, Lublin 1988.

Jonca M., Lamartine'a i Stowackiego rozważania o żeglowaniu, „Litteraria” 2009, nr 37.

Kamionka-Straszakowa J., Almanach, [w:] Stownik literatury polskiej XIX wieku, red. J. Bachórz, A. Kowalczykowa, Wrocław 2009.

Kamionkowa J., Almanachy literackie, [w:] Formy literatury popularnej, red. A. Okopień-Sławińska, Wrocław 1973.

Kipa E., List Słowackiego do A.E. Odyńca i „Dumka ukraińska”, „Pamiętnik Literacki” 1950, nr 41/2.

Kleiner J., Stowacki, Wrocław 1972.

Korespondencja Józefa Bohdana Zaleskiego, red. D. Zaleski, t. 1, Lwów 1900.

Kowalczykowa A., Stowacki, Warszawa 1994.

Kowalska A., Mochnacki i Lelewel. Wspóttwórcy życia umysłowego Warszawy i kraju 1825-1830, Warszawa 1971.

Kuziak M., Wokót „Pisarskiej młodości Stowackiego” Stefana Treugutta, [w:] idem, Fragmenty o Stowackim, Słupsk 2001.

Łanda S., Jak Odyniec redagowat „Czaty” Mickiewicza: z „,Kroniki życia i twórczości Mickiewicza: 1824-1829”, „Pamiętnik Literacki” ” 1982, nr 1/2.

Makaruk M., Antoni Edward Odyniec. Romantyk w zwierciadle biedermeieru, Warszawa 2012.

Makaruk M., Warszawskie lata Antoniego Edwarda Odyńca, [w:] Romantyzm warszawski, red. O. Krysowski, Warszawa 2016.

Małecki A., Juliusz Slowacki: jego życie i dzieła w stosunku do współczesnej epoki, Lwów 1901.

Mickiewicz A., Dzieła, t. 14. Listy, oprac. S. Pigoń, Warszawa 1955.

Odyniec A.E., Przedmowa wydawcy, „Melitele”, Warszawa 1829. 
Odyniec A.E., Wspomnienia z przeszłości opowiadane Deotymie, Warszawa 1884.

Pług A., Antoni Edward Odyniec, „Kłosy” 1885, nr 1046.

Potocki A., Sejmiki literackie $w$ dobie romantyzmu: o noworocznikach $i$ almanachach literackich w pierwszej polowie XIX wieku, „Pamiętnik Literacki” 1902, nr 1/4.

Rymkiewicz J.M., Stowacki. Encyklopedia, Warszawa 2004.

Sawrymowicz E., Kalendarz życia i twórczości Juliusza Słowackiego, współp. S. Makowski, Z. Sudolski, Wrocław 1960.

Seweryn D., Stowacki nie-mistyczny, Lublin 2001.

Słowacki J., Dzieła wszystkie, t. 3, red. J. Kleiner, Wrocław 1952.

Słowacki J., Powieści poetyckie, Wrocław 1986.

Sudolski Z., Inedita wieku XIX w zbiorach Skimborowicza, „Pamiętnik Literacki” 1956, nr 3/4.

Sudolski Z., Słowacki, Warszawa 1996.

Treugutt S., Pisarska młodość Słowackiego, Wrocław 1958.

Ursel M., Wstęp, [w:] J. Słowacki, Powieści poetyckie, Wrocław 1986.

Westermark K., Poeta-urzędnik. Juliusz Stowacki w Komisji Rzadowej Przychodów i Skarbu w Warszawie (1829-1831), [w:] Romantyzm warszawski, red. O. Krysowski, Warszawa 2016.

Witkowska A., Stowacki, Warszawa 1994.

Wójcicki K. W., Kawa literacka w Warszawie, Warszawa 1873.

Zieliński J., Stowacki. SzatAniot, Warszawa 2009.

\title{
Circumstances of Hugo's release, that is Słowacki's debut in the pages of "choice as to the content of almanac"
}

\author{
Summary
}

The author describes in the article the circumstances of publishing the poem Hugo by Juliusz Słowacki in the New Year's "Melitele" edited by Antoni Edward Odyniec. The publication of the poem was the debut of the young poet. The song, described for years as unsuccessful and imitative, has only in the last thirty years gained value and more attention from researchers.

The following aspects of the issue of the debut in "Melitele" were analyzed: the editorial work of Odyniec, the specifics of the New Year in comparison to other publications of this type on the publishing market at the time, its program nature and place in the literary life of Warsaw, as well as opinions expressed about it by readers.

The author tries to show that the choice of "Melitele" for the place of publication of the first piece of print resulted mainly from the living conditions of the young poet, entangled by a kind of social triangle between Salomea Bécu and Odyniec, and facing the discrepancy between the desire for fame and the subsequent reluctance to his own literary practice.

Keywords: Romanticism, debut, debuts of romantics, almanac 